\title{
WEATHER, AGRICULTURE, AND RELIGION IN THE ANCIENT NEAR EAST AND IN THE OLD TESTAMENT
}

\author{
AURELIAN BOTICA* \\ Emanuel University of Oradea
}

\begin{abstract}
The purpose of this paper is to examine those areas of agricultural and religious life that intersected with each and influenced the way people thought of God (or the gods). We will start with the premise that in the Ancient Near East religion was intrinsically connected to agriculture and fertility, though not entirely defined by them. It is also plausible that people shared a concept of God (gods) that at times was shaped by their interaction with natural phenomena like rain, drought, storms, flooding, and animal and crop plagues. In this sense, scholars have noted the connection between "fertility" and religious life, even though some remain caution of pushing this connection too far. To evaluate the strength of this idea we will examine a number of cultic texts that appear to have presumed the link between weather, agriculture and religion. In particular, we will focus on references to weather/storm/ fertility gods. In the later part of our study, we will ask to what extent Biblical men and women were influenced by Ancient Near Eastern religious thought. We will also explore the concept of the link between agriculture, weather and religion in Greek religious texts.
\end{abstract}

Key words: Fertility, Sacred Prostitution Agriculture, Religion, Baal, Bible

\section{Fertility and the Practice of Sacred Prostitution}

In one of our earlier studies, we made the case that "Ba'al worship may have also touched on the issue of sexuality. The consort of El was Ashtoreth, the 'Lady of the Sea', and the sources show that their relation involved sexual intercourse". ${ }^{1}$ In fact, "it was the sexual intercourse between primordial deities that made possible the

AURELIAN BOTICA (PhD Hebrew Union College, Jewish Institute of Religion, Cincinnati, Ohio) is Lecturer in Biblical Studies at Emanuel University of Oradea, Romania. He is the author of The Concept of Intention in the Bible, Philo of Alexandria and the Early Rabbinic Literature (New York: Gorgias Press, 2011).

1 Botica, "The Theophoric element Baal in Ancient Phoenician Inscriptions", Perichoresis 10.1 (2012): 67-94, with references to Morenz, Egyptian Religion (Ithaca, NY: Cornell University Press, 1992), 162-63; von Soden, The Ancient Orient (Grand Rapids, MI: Eerdmans, 1985), $212 \mathrm{ff}$; Walton, Ancient Israelite Culture in Its Ancient Context (Grand Rapids, MI: Zondervan, 1990), 24ff; Z. Zevit, The Religions of Ancient Israel (New York: Continuum, 2001), 649, "for the fact that archaeological data show that pair-deities are attested even in the worship of ancient Israelites". 
birth of all other gods". In our study we also argued that one of the practical implications of this belief was the practice of "sacred prostitution". Specifically, the Sumerians and possibly the Canaanites held sacred celebrations where

The king would join a procession to the temple of the goddess Inanna and there he engaged in a sexual relationship with the priestess of the temple, who symbolized Inanna. The sexual union was seen as an enactment of the primordial union between Dumuzi, a Sumerian shepherd god, and Innana, the goddess of sexual love, procreation and fertility. The sexual reenactment assured that "the forces of agricultural renewal were set in motion by sexual union... Naturally, the pagan worshiper expected that acts of cultic prostitution would impact the fertility of the land".

On the practice of "Sacred Marriage", Klein observed that its purpose was to secure the fertility of humans and the land in Mesopotamia and in Assyrian and Babylonian religious practices. ${ }^{3}$ The ritual of sacred marriage could involve both sexual intercourse between a priestess and the king, and also bringing the statues of the goddess Inanna into the royal chamber; that is, a symbolical presence of the goddess in the chamber where the king would engage in direct intercourse with his consorts who played the role of the goddess. In this sense, the act itself would have been considered a union between the king and the goddess itself.

We have also argued that scholars have taken contrasting views on this matter; some interpreting the texts on their face value, while others arguing that the data is insufficient to warrant a clear picture of the practice of sacred prostitution. ${ }^{4}$ For the last group, the argument was made that some of the biblical passages that refer to possible sexual acts within the cult do in fact employ metaphorical language. They hold to the view that the biblical authors used symbolism (physical, sexual acts) to describe a "spiritual" reality: hence the definition of apostasy of the people of God. ${ }^{5}$

Note Sefati, Y. Love Songs in Sumerian Literature (Tel Aviv: Bar Ilan University Press, 1998), 208ff; Johanna Stuckey, "Innana and the 'Sacred Marriage”, http://www.matrifocus.com/ IMB 05/ spotlight.htm, and http://www.matrifocus.com/ SAM05/ spotlight.htm, and Frymer-Kensky, In the Wake of the Goddesses (New York: the Free Press, 1992), 50ff, for the controversy of the theology and practice of "sacred prostitution".

3 J. Klein, "Sacred Marriage", The Anchor Bible Dictionary, ed. by D. N. Freeman (New York: Doubleday, 1992), 5:866-70.

4 For the consensus that the biblical passages reflect the historical practice see Thus Brooks, "Fertility Cult Functionaries in the Old Testament", Journal of Biblical Literature 60 (1941): 227-253; Andersen and Freedman, Hosea, Anchor Bible (New York: Doubleday, 1980), 369-70; Stuart, Hoseah-Jonah, WBC (Waco, TX: Word Publishing, 1987), 83-84; J. Stuckey, "Ancient Mother Goddesses and Fertility Cults", Journal of the Association for Research in Mothering 7.1 (2005), 38ff. Thus J. Tigay, Deuteronomy, JPS Torah Commentary (Philadelphia: Jewish Publication Society, 1996), 481; Barstad, The Religious Polemic of Amos (Leiden: Brill, 1984), esp. 26ff; Marsman, Women in Ugarit and Israel: Their Social and Religious Position in the Context of the Ancient Near East, Oudtestamentische studiën vol. 49 (Leiden: Brill, 2003), 497; one should understand that even 
Finally, a mediatory position has held to the historical possibility that certain cultures practiced sacred prostitution, "but that these represented fringe elements in the religious landscape of Israel". As Bird argued, "the isolated biblical references

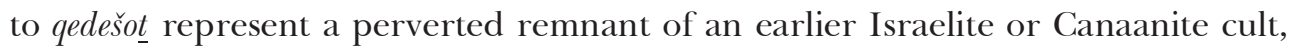
perpetuated in a perverted Israelite cult". ${ }^{6}$

The fact remains that Biblical texts appear to describe real-life experiences, not only spiritual realities depicted with the help of material symbols. Granted, the Scripture used symbolical language to refer to inward attitudes, such as "prostituting" oneself with the Baals. Yet, not all passages fall under this category, even though many of these verses do in fact describe a spiritual condition of the heart. In this sense, we would want to ask "why would the Bible use these metaphors so often and with such pathos, if they had no correspondent in the realm of everyday life?" Likewise, "why would the Bible employ a metaphor from an unknown practice in order to address such a critical issue as idolatry?"

\section{Weather Gods and Fertility in Canaan}

In our study "The Theophoric element Baal in Ancient Phoenician Inscriptions", we also made the argument that the name Baal was extremely popular in the Ancient Near East, not only in the religious texts, but also as a theophoric element, both within the confines of Israel and in Phoenicia. ${ }^{8}$ The assertion that Ba'al was a deity of fundamental significance in the Ancient Near East is confirmed "by the frequency of $\mathrm{Ba}$ 'al as theophoric component in personal names". ${ }^{9}$ In fact, when the Israelites came into Canaan, Baal worship had been established for several hundred years. ${ }^{10}$ Along with Ashtoreth and El, Baal was one of the most important deities of

within this group there exists a wide range of variation when it comes to solving the dilema of the biblical reference to "sacred prostitution".

6 Phyllis Bird, "To Play the Harlot: An Inquiry into an Old Testament Metaphor", Gender and Difference in Ancient Israel, ed. by D. Peggy (Minneapolis, MN: Fortress Press, 1989), 75-94.

7 Botica, "The Theophoric element Baal in Ancient Phoenician Inscriptions", Perichoresis 10.1 (2012): 67-94.

8 Aurelian Botica, "The Theophoric element Baal in Ancient Phoenician Inscriptions", Perichoresis 10.1 (2012): 67-94. Note also Zevit, The Religions of Ancient Israel (New York: Continuum, 2001), 596; Bright, A History of Israel, 3rd edn. (Philadelphia, PA: Westminster, 1981), 241; Smith, The Early History of God (Grand Rapids, MI: Eerdmans, 2002), 76ff; Block, "God (1.5. Ba'al)", Dictionary of Old Testament Historical Books, ed. by B. T. Arnold (Downers Grove, IL: Intervarsity Press, 2005), 341ff; and Kaufmann, The Religion of Israel, trans. by M. Greenberg (New York: Schoken Books, 1960), 123; Tigay, You Shall Have No Other Gods: Israelite Religion in the Light of Hebrew Inscriptions (Atlanta, GA: Scholars Press, 1986), 30; Schmitz, "Phoenician Religion", The Anchor Bible Dictionary (New York: Doubleday, 1922), 5:358, and Lipinsky, "The Phoenicians", Civilizations of the Ancient Near East, 2 volumes, ed. by J. M. Sasson (New York: Scribner, 1995), 2:1321-22.

$9 \quad$ "Ba'al", Dictionary of Deities and Demons in the Bible, 133.

10 Note Botica, "The Theophoric element Baal in Ancient Phoenician Inscriptions", Perichoresis 10.1 (2012): 67-94, for the origins of the Baal religion in Ugarit; specifically, the 14th century Baal Cycle, "one of the documents that laid the ground for all subsequent derivations in $\mathrm{Ba}$ 'al 
Canaanite religion. By establishing the connections between agriculture, fertility and religion, one would understand why Baal worship became so appealing to ancient Israel.

Craigie too noticed that in Canaan, as well as in other Ancient Oriental religions, the religious world was dominated by "principal", "minor" and "regional" deities. ${ }^{11}$ The difference between principal and minor deities can be observed best both by the number of artifacts discovered within the ruins of ancient temples, as well as in inscriptions and religious cultic texts. Due to the pressures of living in an agricultural society, "from the time of the entry into the land, the people had accepted somewhat fully the Canaanite theology which credited Baal with this bounty". ${ }^{12}$ In this sense, the annual cycle of rites that commemorated the death and the resurrection of the god "were magical". Without the cooperation of the people "neither magic nor the gods nor any other conceivable power would bring back the season of growth and reproduction". In this sense, the people were "custodians of nature and its changes". The texts indicate that "results in the form of fertility could and would come only as men voluntarily chose to perform the necessary magical rites". There existed a mysterious force that transcended the power of the gods and magic was the key to unleash the force for the benefits of the humans.

Different texts list some of the magic rites and cultic objects that reveal the worldview of the ancient man regarding "fertility". ${ }^{13}$ Among the cultic objects that assist in rituals, the texts refer to baked clay pipes were poured into the ground through libations, holes made at various levels in the pipe that allowed liquid offerings to flow away into the soil, a number of pots that were buried at the lower end of the pipe, double vessels which would allow two liquids to be poured out at the same time, statuettes of the "naked" goddess where her genitalia and breasts are made evident for the purpose of assuring fertility, and the "mandrake", which was thought to possess the quality of curing bareness. In one of the texts listed by Schaeffer, we read:

Plant some mandrakes in the earth,

Pour deep into the heart of the earth the $s l m$

Empty the jar deep into the heart of the fields

Do this and thine orchard, thy trees, thy husbandry will be with me.

theology", and references to Smith, The Ugaritic Ba 'al Cycle (Leiden: Brill, 1994/ 2009); The Early History of God (Grand Rapids, MI: Eerdmans, 2002), $28 \mathrm{ff.}$

11 P. Craigie, "Religions: Canaan", International Standard Bible Encyclopedia, ed. by W. Bromiley (Grand Rapids, MI: Eerdmans, 1988), 95-101.

12 W. Irwin, “The Hebrews", The Intellectual Adventure of Ancient Man, H. Frankfort et all eds. (Chicago, IL: University of Chicago Press, 1946), 296-97.

13 Thus C. Schaeffer, The Cuneiform Texts of Ras Shamra-Ugarit (London: Brittish Academy, 1939), 46.

PERICHORESIS $11.1(2013)$ 
Rituals such as these attest the fact that the people of Canaan worshipped Baal as "the owner of the land and the dispenser of its gifts". ${ }^{14}$ In this sense, for the pagan worshiper the boundary between the divine and the natural was blurred; intentionally so. Eichrodt underlines the "the naturalistic character of these deities", in the sense that

They have their being in the natural phenomenon of their district, in the vegetable and animal life, and in the natural resources on which these depend for their growth, springs and rivers, the storm and the heat of the sun. Hence fertility rites, with their physical mimicry of natural processes, play a great part in the cult.

The fact that religious practices had so much to do with fertility is evident in the fact that the god El, who was the main protagonist in the Ugaritic myth "Birth of the Good Gods", has the epithet "the Bull" and is active in birthing the other gods. ${ }^{15}$ As various scholars argued, the bull and the calf symbolized both "power and fecundity throughout the Ancient Near East world" ${ }^{16}$ Although we may never fully comprehend the reason why Aaron agreed to build the two calves in the Sinai desert, it is very likely that the people would have associated the god Apis with the symbol of power, the exact prerogative that would have served the Israelites in the vast desert.

One will note that many other gods exhibited traits similar to those of Baal. It is possible that neighboring cultures worshipped the same divinity under different names. This appears to have been the case with the god Adad in Assyria. ${ }^{17}$ Adad had the power to withhold or release rain and the winds. When weather changed, the pagan worshiper believed that it was Adad who roared in the clouds. Likewise, the god Dagan, who had control over the grain and fertility of the crops, was considered the father of Baal. ${ }^{18}$

One important dimension of Baal worship was the association of the life of the god with the cycles of agriculture. One of the early mythical accounts, the Baal Cycle, deals with the conflict between Baal, who had been crowned king of the gods, and Mot. Baal descended into the underworld of god Mot, the god of death, and in the

Thus W. Eichrodt, Theology of the Old Testament, vol. 1 (Philadelphia, PA: Westminster Press, 1961), 200-203.

15 D. T. Tsumura, "Canaan”, Dictionary of the Old Testament Historical Books, ed. by B. T. Arnold (Downers Grove, IL: Intervarsity Press, 2005), 122-32; A. H. W. Curtis, "Canaanite Gods and Religion”, Dictionary of the Old Testament Historical Books, ed. by B. T. Arnold (Downers Grove, IL: Intervarsity Press, 2005), 132-42; C. Van Dam, "Golden Calf", Dictionary of the Old Testament Pentateuch, ed. by T. D. Alexander (Downers Grove, IL: Intervarsity Press, 2003), 368-71.

16 C. Van Dan, "Golden Calf”, 369.

17 See B. T. Arnold, Readings from the Ancient Near East: Primary Sources for Old Testament Study (Ada, MI: Baker Academic, 2002), 26, 29, for The Epic of Atra-khasis and references to Adad as the god of weather and the clouds.

18 Kapelrud, Baal in the Ras Shamra Texts (Copenhagen: G. E. C. Gad, 1952), 54.

PERICHORESIS $11.1(2013)$ 
struggle that ensued he was killed. ${ }^{19}$ The goddess Anat searched for Baal, found his body and buried it. As Kapelrud notes,

While the trees were thriving under the rain they were scorched when Baal had to disappear into the earth. So were also the olive and other products of the earth. The god was god, so was the rain, then also fertility. As soon as the god is back, the whole picture changes. ${ }^{20}$

As scholars argued, the fact that a rainless summer follows upon the winter rain is explained by the assertion that "Ba'al has gone to the world of the dead and taken along his clouds, his winds, his team of horses, and his rain". ${ }^{21}$ Rain and clouds disappeared; the dry season was coming. The activity of Baal represented "the rainy and most fertile part of the year", without which the dry part meant drought and famine.

In the worldview of the myth, Anat attacked and overcame Mot. In the end, Baal was raised from the dead, confronted Mot himself and regained his throne. In the first journey of Baal to the underworld, he was accompanied by many animals. Baal copulated with a heifer, which bore him a heir. Scholars believe that this gesture was meant to signify that Baal would assure the ongoing forces of fertility even while he went into the underworld..$^{22}$ The reference to "baals" signifies the fact that people worshipped the local manifestations of a single deity.

\section{Agriculture and Religion: the Cultic Texts}

When we review the data that pertains to this dimension of the problem, we will notice as many differences as some have underlined the similarities. Clearly there existed a wide gulf between the Canaanite and the Israelite explanation of reality; particularly with respect to sex and the divine world. ${ }^{23}$ Our current study has amply demonstrated the obsession of Canaanite religion with divine sexuality as the cause of fertility. Yet, the Hebrew understanding of divinity lacked anything having to do with death, resurrection, sexuality or battles among the gods. God had no consort, nor did He engage in sexual acts in order to create progenitors or bring fertility. their allies, the forces of chaos and the enemies of Ugarit.

20 Kapelrud, Baal in the Ras Shamra Texts, 94.

21 See $K T U, 1.5 \mathrm{v}, 7 \mathrm{f}$. It is important to note that the Canaanites accounted for other conflicts of Baal besides the one between him and the god Mot. For the epic battle between Baal and the god of the waters Yam see J. A. Montgomery, "Ras Shamra Notes IV: The Conflict of Baal and the Waters", Journal of the American Oriental Society 55.3 (1935), 268-277.

22 See A. H. W. Curtis, "Canaanite Gods and Religion", 132-42.

23 J. P. Free, Archaeology and Bible History, rev. by H. F. Voss (Grand Rapids, MI: Zondervan, 1992), 85-86, citing the Ras Shamra references to El and his wives: "he shall cleanse their lips, shall lift them up; their lips are sweet, sweet like the pomegranate. With them is kissing and conception". 
This remains a crucial detail in the debate concerning the origins of Israelite festivals.

\section{Biblical Festivals}

That both the Hebrews and the Canaanites held festivals at the same moments during the year is a truism. That they explained their historical origins in radically different manner, assigned markedly different roles to their respective divinities, and celebrated them in such diverse ways, is another uncontested fact.

As scholars noted, the Hebrews celebrated three major Festivals. Chronologically, the first feast was the Passover. It was celebrated on the 15th day of the first month, coinciding the early Spring. Roland de Vaux argued that the Passover was "seen to be an ancient rite practiced by shepherds" where ancient people sacrificed "a young animal in order to secure fecundity and prosperity for the flock". ${ }^{24}$ Regardless of how other people understood this feast, historically, the Bible connects the Passover with "the divine salvation of Moses' people from Egypt". As Israel's religion was a historical religion, each major feast was based on the celebration of God's intervention in the history of His people. As such in the "Spring time there had been a miraculous intervention by God. He redeemed the Israelites from Egypt. The feasts of Passover and the Unleavened Bread commemorated this event, even if in the surrounding cultures it coincided "with the spring rites of shepherding and agriculture".

Second, the Feast of the Unleavened Bread "marked the beginning of the barley harvest, which was the first crop to be gathered". ${ }^{25}$ As the Old Testament describes it, for "the first seven days of the barley harvest only bread made with the new grain was eaten". From a calendaristic point of view, "the characteristic feature of this feast lay in a first offering of the first-fruits". De Vaux argues that "the feast of Unleavened Bread was merely a preparation" for "the real feast" of the harvest, which was the feast of Weeks. Here, the Hebrew "marked the end of the cereal harvests". Together, the two feasts "marked the beginning and the end of harvest-time".

Third, the Feast of the Weeks celebrated one of the most important crop of the year: wheat. It was "celebrated seven weeks after the first cereal had been cut off, i.e., seven weeks after the Unleavened Bread feast". As the first feast marked "the new beginning in the harvest" (eating unleavened bread), the second celebrated "the end of the harvest: leavened bread was baked, harvest was over". Scholars have shown - correctly so- that these feasts presuppose a "settled agricultural life". This, however, does not mean that agricultural events were the only concern for the Hebrews. If the Passover Feast celebrated the liberation of the Hebrews from Egypt, the Feast of the Weeks coincided with the giving of the Law at Mount Sinai (Exodus 19:1ff). The fact that, having conquered Canaan, the Israelites celebrated the same 
agricultural event with the Canaanites, does not mean that the giving of the Law on Mount Sinai was a mythological creation. ${ }^{26}$ The mere fact that other pastoral cultures held celebrations in the first month, does not prove that the Liberation from Egypt was a mythological invention of the Israelites, in order to justify their historical origins. ${ }^{27}$ Evidently, the Old Testament "makes no assumption that all these feasts were invented by Moses' group".

The fourth major festival was The Feast of Booths, which was celebrated at the beginning of the autumnal year. This "ingathering" feast was the most joyous agricultural celebration of the year. ${ }^{28}$ When all the main types of fruits were gathered and the olives and the grapes were pressed, the Israelite man and woman knew that God watched over them for one more year. For many people, this meant mere survival, and they would be thankful to celebrate life in a festive celebration. But beyond the agricultural significance, in the Feast of Booths the Israelites recreated the environment that reminded them of the wandering in the wilderness and the liberation from Egypt. One should not miss in these celebrations the blending of the history of God and His people with the realities of economic and social life.

Equally important in the seventh month was the Day of Atonement. Although it occurred during a season of high economic impact, the Yom Kippur had a profound religious significance (Leviticus 23:27). ${ }^{29}$ In addition to sacrifices, prayers and purifications, the Israelites were commanded to "afflict" their souls. This command, while describing the practice of fasting, it alluded to the attitude of solemnity and repentance that had to characterize every participant.

The fact that, at Yom Kippur, the Bible lays emphasis on penance and the blotting of sin, places this celebration in a category of its own among Ancient Near Eastern rituals. We do not mean to suggest the notion of atonement existed only in the

By the same logic, the Early Church should have "invented" the Easter Sunday, in order to ground the "mythological" death and resurrection of Christ in the Feast of Passover, and thus link the celebration of the Liberation of Israel with the salvation of humanity from sin through the death and resurrection of Jesus Christ. To prove this "forging" of history one must prove first the non-factuality of the death of Jesus during the Easter Feast. However, both biblical, as well as Jewish and Pagan sources, attest to the historicity of this event. D. Alexander (Downers Grove, IL: Intervarsity Press, 2003), 300-313, for the fact that the "idea of feasting is as old as humanity", but for ancient Israel each feast told part of the story of Yahweh's redemption and formation of His people Israel.

28 Note de Vaux, Ancient Israel, 495-502; Stuart, Exodus, 536; D. L. Christensen, Deuteronomy 1:121:9, second edn., Word Biblical Commentary (Nashville, TN: Thomas Nelson, 2001), 345-52; T. Kronholm, "Sakak", Theological Dictionary of the Old Testament, ed. by G. H. Botterweck (Grand Rapids, MI: Eerdmans, 1999), 10:236-54, especially for the theological nuances of the word outside its references to the Festival of the Booths.

29 Thus B. Lang, "kipper”, Theological Dictionary of the Old Testament, ed. by G. H. Botterweck (Grand Rapids, MI: Eerdmans, 1995), 7:289-303, de Vaux, Ancient Israel, 507-10; D. P. Wright, "Day of Atonement", Anchor Bible Dictionary, ed. by D. N. Freeman (New York: Doubleday, 1992), 2:7276 . 
Israelite cult. Yet, the time in the agricultural cycle that was chosen to celebrate Yom Kippur, points to a very different religious mentality on the part of the Israelites. The gravity of sin, linked with firm historical events, sets Yom Kippur in a stark contrast with Canaanite practices.

We may add that there exists a general consensus among scholars, concerning this contrast. ${ }^{30}$ True, in both cases, agriculture played on important role, as people recognized and celebrated the role of the divine in bringing fertility to the worshipers. But the similarities ended there. Canaanite religion had no place for the emphasis on sin and repentance that characterized the Yom Kippur. In fact, the festivals through which the Canaanites celebrated the god Baal made sense only to the extent that they celebrated the rising of Baal and stirred the forces of fertility (sexually and otherwise) for the purpose of ensuring human and animal fertility.

Very often, in the Bible the blessings of offspring are conditional upon the people keeping their covenantal obligations. In times of crisis, the people's moral or ethical failure is connected with the problem of infertility. ${ }^{31}$ We also noted that the struggle with infertility was felt not only in realm of the family, but also in the relation of the Israelite worshiper with the land. Here too the Biblical vision linked disobedience with drought, invasion of locusts and other calamities that deprived the people of the crops and fruits needed for survival. ${ }^{32}$ One of the causes that gave Israelites reasons to be concerned was the lack of rain at the time when people needed it the most. For the Biblical writers, the absence of rain could be a sign of moral failure and an occasion for fasting and repentance. ${ }^{33}$ The event of the absence of rain was also the stage on which YHWH confronted the gods of Canaan; in particular, Baal, the "rain bringer" and the "rider of the clouds".

Evidently the Bible places a higher emphasis on the moral and ethical cause for success or, conversely, failure in these areas of life, than other sacred texts do. It is true that not all catastrophic events were viewed from this perspective. The expression "Now there was a famine in the land" (Genesis 12:10) appears a simple account of an experience that many Ancient Near Eastern people faced regularly. The fact, however, that such an event formed the background to the migration of Abraham festivals.

31 For texts that deal with the relation between faith and human reproduction see Genesis 16:11; 20:17; 29:31; 30:2, 22; Exodus 23:26; Leviticus 26:9; Deuteronomy 7:13; 32:18; 1 Samuel 1:6, 19-20; 2:5; 2 Kings 4:14, 17; Hosea 9:11.

32 For important passages on this issue see Genesis 1:11, 29; 27:28; Exodus 23:25; Leviticus 23:3; Deuteronomy 32:13; 2 Samuel 21:1, 14; 24:13; Isaiah 9:9; 17:1 1; 18:5-6; 19:7; 32:10, 15; Hosea 2:8,12, 21; Joel 2:19; Micah 4:4; 6:14; Psalms 50:10; 65:9-11; 72; 104:14.

33 Among the most representative passages that deal with this issue are Genesis 27:28; Exodus 15:8, 10; Leviticus 26:3; Deuteronomy 8:15; 2 Samuel 21:14; 1 Kings 8:35, 37; 17:1f; 18:1, 45; Isaiah 29:23; 30:23; 32:15; Hosea 2:21; 6:3; Joel 2:23; Amos 4:7; Jeremiah 3:2-3; 10:12;14:22; Psalms $18: 9 ; 29 ; 65: 9-11 ; 68: 4,8,33 ; 89: 11$.

PERICHORESIS 11.1 (2013) 
into Egypt - which in itself played a minor, but important, role into the larger narrative of redemption-leads us to conclude that from the perspective of the Biblical authors, all natural events had a well-intended purpose. And very often, the way people responded to the prompting of God could affect the order of natural life. Old Testament thinking, more than any other religious environment, viewed natural happenings through the moral lenses of $\sin$ and/ or holiness. There "were "natural' links between attitudes to YHWH, attitudes to one another and the fate of the land" ${ }^{34}$ Likewise, the very first breaking of the moral law affected nature in an irreversible way. God could use nature to bless or to punish His creatures. ${ }^{35}$

\section{Ancient Near Eastern Festivals}

A number of cultic texts from Ras Shamra and other locations describe the procedures of the Temple service during the agricultural seasons of the year. ${ }^{36}$ The Canaanite emphasis on fertility became evident in the way people celebrated the festivals; religious, agricultural or both. In fact the calendar was one of the best indicators of the emphasis that Canaanite religion placed on agriculture. As Mulder noted, during the New Year, which was celebrated in the Autumn, people placed a high emphasis on "the first of the wine" in the months of September-October. ${ }^{37}$ This was primarily a "vintage festival where Baal's return from the underworld and his enthronement on Mt. Sapan were probably celebrated". It is possible that the book of Judges describes this practice in chapter 9:27,

And they went out into the field and gathered the grapes from their vineyards and trod them and held a festival; and they went into the house of their god and ate and drank and reviled Abimelech.

As god of the storm, Baal was venerated for his power to bring much needed rain to societies that depended almost exclusively on agriculture; thus the epithet "the rain bringer".

See then, the season of his rain

Baal appoints, the season of... in wells

he gives forth his voice in the clouds

he flashes lightning to the earth. ${ }^{38}$

\footnotetext{
34 In this sense see J. Goldingay, Old Testament Theology: Israel's Faith, vol. 2 (Downers Grove, IL: Intervarsity Press, 2006), 305-06.

35 Thus C. J. H. Wright, Old Testament Ethics for the People of God (Downers Grove, IL: Intervarsity Press, 2004), 129-31.

36 Parts of these primary texts were also cited in A. Botica, "'When Heaven is Shut up. Ancient Near Eastern Backgrounds to the Concept of Natural Calamity,"” Perichoresis 4.1 (2006): 95-115.

37 Thus M. J. Mulder, "Ba'al”, Theological Dictionary of the Old Testament, 2:190ff.

$38 \quad K T U, 51: \mathrm{V}: 68$.
} 
Unto the earth Baal rains

And unto the field rains 'Aliyy

Sweet to the earth is Baal rain

And to the field the rain of Baal. ${ }^{39}$

Yet, before the rain season, and after the Autumn, the earth passed through a period of inactivity and bareness, which the pagan man attributed to the death of Baal. Cultic texts that regulated this season show the officiates crying out "Where is Aliyan Baal? Where is the Prince, Lord of Earth". ${ }^{40}$ Baal was killed; consequently all vegetation disappeared and human life itself was engendered:

Aliyan Ba'al is dead! The Prince, the Lord of Earth is perished!...

What becomes of the people? Dagon's son! What of the masses $!^{41}$

During Spring, the Temple officiants responded with joy to the advent of rains and thunderstorms, because the return of vegetative life meant the return of Ba'al to life.

Alive is Aliyan Ba'al! Existent the prince, the Lord of the Earth! ...

the heavens fat did rain, the wadis flow with honey!

... the springs of the fields babble... a god has made them flow

the lord of the springs of the land. ${ }^{42}$

Another festival was the Dedication of the Temple, celebrated during the time of the Spring equinox". The Canaanites followed this with the Festival of the Destruction of god Mot, in the month of June. In a sense, this was also a "rite of the last sheaf". Now, a number of scholars have suggested that the early Hebrews borrowed their agricultural festivals from Canaanite culture. The assumption is made that, since the Canaanites were settled agriculturalists, and the Hebrews were not, it would have been impossible for Mosaic religion to establish a calendaristic system based on the cycles of agriculture in the wilderness, or during their history in Egypt. ${ }^{43}$

In a sense, it is evidently the case that there exist a number of similarities between the agricultural festivals of these two cultures. After all, they shared the same land

KTU, 126:III:5-8.

Keilschrift Texte aus Ugarit (KTU), here as The Cuneiform Alphabetic Texts from Ugarit, Ras Ihn Hani, and Other Places, KTU 2nd edition, M. Dietrich, O. Loretz, J. Sanmartin eds. (Münster: UgaritVerlag, 1995), 49:IV:28.

Thus KTU, 1.5 VI. 9, 23-25, and J. B. Pritchard, Ancient Near Eastern Texts, third edn. with supplement (Princeton, NJ: Princeton, 1974), 139 (henceforth $A N E T$ ). KTU 1.6.III. 6f, 12f, 25-27; ANET 140.

Thus A. C. Violita, "The Role of Migrants in the Transfer of Culture and Acculturation", Frontiers in Migration Analysis, ed. by R. B. Mandal (New Delhi, India: Concept Publishing Company, 1981), 336; F. M. Cross, Canaanite Myth and Hebrew Epic: Essays in the History of the Religion of Israel (Harvard, MA: Harvard University Press, 2009), 106. 
during the same period of time. However, the question that one needs to raise is not whether the Israelites and the Canaanites shared the same festivals, but whether the religious vision that shaped the festivals was itself identical, or not. In other words, we must ask how people explained the cosmic cycles of nature in relation to their history. As Kaufmann argued,

The Bible conceives of idolatry as the belie that divine and magical powers inhere in certain natural or man-made objects and that man can activate these powers through fixed rituals. These objects, upon which magical rituals are performed, are "the gods of the nations". ${ }^{44}$

One may note that the myth of the disappearing god was popular in other cultures as well. For example, in The Wrath of Telipinu (second millennium), the disappearance of Telipinu-an Anatolian storm-god-prompted an expiatory ritual which included a mythological account of the deity's displeasure, departure, and reconciliation. $^{45}$

An eya-tree stands before Telipinu. From the eya-tree hangs a hunting bag... In it is mutton fat. In it are grain, the fertility of the herds, and the grape. In it are cow and sheep. In it are long years and progeny (italics mine). ${ }^{46}$

The same logic is evident in the inscriptions on the Baal Temple at Ras Shamra:

Put bread in the earth

Place mandrakes in the dust

Pour a peace offering in the midst of the earth

A libation in the midst of the fields

On them are horns

like bulls and humps

like buffaloes

And on them is the face of Ba'al (75:I:26-33).

Unto the earth Baal rains

And unto the field rains 'Aliyy

Sweet to the earth is Baal rain

And to the field the rain of Baal (126:III:5-8).

$44 \quad$ Kaufman, The Religion of Israel, 14.

45 See W. Hallo, "The Wrath of Telipinu", The Context of Scripture. Canonical Compositions from the Biblical World (Leiden: Brill, 1997), A. iv. 27-31. See also Kapelrud, Baal in the Ras Shamra Texts, $38 \mathrm{ff}$, for a discussion of Telepinu.

$46 \quad$ Kapelrud, Baal in the Ras Shamra Texts, $38 \mathrm{ff}$.

PERICHORESIS 11.1 (2013) 
As Kapelrud argued, Baal

was responsible for the distribution of rain, a necessity for all kinds of fertility in this part of the world, where the rain and not the flowing rivers as in Mesopotamia and Egypt makes the grass grow again after the dry summer period. Therefore Baal was one of the most important gods, if not the most important. He was not a god living only in literature; his life and death meant life and death of farmers and cattle-breeders and thereby to the whole society. ${ }^{47}$

Baal, as the Rider of the Clouds, commands control over the sources of water, both on earth and in the sky.

See then, the season of his rain

Baal appoints, the season of... in wells

he gives forth his voice in the clouds

he flashes lightning to the earth. ${ }^{48}$

El has become old; his spouse therefore decrees:

"From now on et Ba'al set the time of his rain,

the time of becoming rigid as ice,

the resounding of his voice from the clouds,

the hurling of lightning to the earth" ${ }^{49}$

As we mentioned in the beginning of our study, the fact that the earth could bring forth fruit was due both to rein and sexuality. G. Ostborn pointed to the embodiment of Baal as a bull who impregnates the goddess Anat, herself under the image of a cow. ${ }^{50}$ And, as Kapelrud argued, the progenitor "is a necessary process of the bull-god; it creates not only progeny but it also furthers fertility for animals, grass and trees, yea, even for man'." ${ }^{1}$

Furthermore, one will note how vital is the relation between the earthly king, queen, land and the gods, in The Ritual and Prayer to Ishtar of Nineveh $(5,7,11,13)$ :

$47 \quad$ Baal in the Ras Shamra Texts, 25.

$48 \quad K T U 5.1: \mathrm{V}: 68$.

49 KTU 1.4.V:6-9. On the relation between "rain" and pagan religion see also H.-J. Zobel, "matar", Theological Dictionary of the Old Testament, ed. by G. J. Botterweck (Grand Rapids, MI: Eerdmans, 1997), 8:250-65, esp. 260-61. Zobel notes that "rain seems to have been a part of theophany and of Yahweh-war from the very beginning, where it expresses Yahweh's sovereign power and strength as experienced by his people from the beginning of its history".

50 G. Ostborn, Yahweh and Baal. Studies in the Book of Hoseah and Related Documents (Malmö, Sweden: C. W. K Gleerup, 1956), 15.

51 Baal in the Ras Shamra Texts, 97. 
(O Ishtar), (if you are) in... then come from... Come away from these countries. For the king, the queen (and) and the princes bring life, health, strength, longevity, contentment(?), obedience (and) vigor, (and) to the land of Hatti growth of crops, vines, cattle, sheep (and) humans.

The diviner breaks one thin loaf for Ishtar of Nineveh and crumbles it into the spring... The diviner says these words, and when they attract (lit. pull) her with the thick loaf, they fill a KUKUB-vessel with water besides... ${ }^{52}$

As Zobel notes, ironically, the sounds of "the thunder, the rushing of rain, and the bubbling of springs" bring great relief both to the gods and the human beings of Ugarit, "since they can now face the immediate future with joy and confidence". And again, Ba'al relies on a female deity: the "Rb", the "goddess of the drizzling rain', mother of Tly, the 'dew goddess', who is one of Ba'al's daughters" ${ }^{53}$ As Kaufman pointed out, "mountains, springs, rivers, and forests have their gods also. The gods have sexual qualities, the existence of male and female deities being essential to pagan thought".${ }^{54}$ Keel and Uehlinger documented the fact that the weather god was often portrayed along with his consort. In the Old Syrian cylinder seal decoration, the encounter between the weather god and the goddess "demonstrates her readiness for engaging in love-making by pushing her clothes aside". ${ }^{55}$

\section{Religious Syncretism in Ancient Israel}

The Old Testament reflects the concern of the people for all matters pertaining to agriculture. All phenomena that affect the land, water and sky played a critical role in the mentality of the worshippers. ${ }^{56}$ In a sense, this notion explains why the Old Testament had so much to say in this matter.

The Importance of Land

Life in Israel, like in the other surrounding societies, depended almost exclusively on land and weather. The majority of people worked the land. Many on them did so in order to survive; only a few afforded to spend time on activities other than toiling for food. It is not a coincidence, then, that the religious vision of the Old Testament regards the land as crucial. Likewise, this is why the theme of the "land" received a from the Biblical World (Leiden: Brill, 1997).

Ibid., 8:262, and $K T U, 1.4: \mathrm{I}, 17$.

Kaufman, The Religion of Israel, 8-9.

Gods, Goddesses and Images of God in Ancient Israel (Minneapolis, MN: Fortress Press, 1998), 38-39.

One has only to consider the plagues against the river Nile in the book of Exodus, to approximate how critical "water" was for the Egyptian worshippers. The turning of the Nile waters into blood, the death of all fish, and the swarming of the frogs from the Nile represented a direct attack on Hapy, one of the most venerated deities in Egyptian religion. 
special attention, not only in the Old Testament, but in the New Testament as well (especially under the concept of "kingdom").

Old Testament sources affirm that the land is the gift of God. The Israelites are tenants who received the land under tenure from God. C. J. H. Wright pointed out that "for a nation of arable and pastoral farming like Israel, land was the only permanent possession". ${ }^{57}$ Permanent, in the sense that "crops and herds and habitations might be destroyed by drought or war, but the land would recover". As various scholars have shown, the promise of the "land" was one of the most important blessings in the covenant that God made with Abraham, Isaac and Jacob. As Wright noted

Beyond the Pentateuch, the land remains a primary theme: its capture and division in Joshua; the struggle to survive on it in Judges; the eventual complete control of the whole territory under David and Solomon; the prophetic protest at injustices perpetrated on the land; the Exile as divine judgment and the people's eventual restoration to the land as a token of a renewed relationship with God. And beside all this there are all kinds of laws, institutions, and cultic practices concerned with the use of the land..$^{58}$

As Ezekiel charged, even notions such as sin and rebellion made so much sense when judged in light of the wicked ways that the people practiced in the "land" (36:17).$^{59}$ It is interesting that the word that Ezekiel uses for "land", to link the sin of the people with the defilement of the country, is "adamah", that is, "cultivated ground" or "soil" that produces plants and crops ${ }^{60}$ One should not think of the "soil" only in relation to crops or plants, but also olive trees and vineyards- the very staples of human subsistence. Among the blessings that Deuteronomy affirms that God will pour out on the Israelites, if they obeyed the covenant, were "the fruit of the ground" (Deuteronomy 30:9). Yet Moses predicted that the people will disobey God and will give the idols credit for the "milk and honey" that they enjoyed in the land (Deuteronomy 31:20). That is why God will punish their sins by striking the land with drought and locusts (Deuteronomy 28:38).

\section{The Practice of Syncretism}

Water, grain, wine and oil were the basic staples of human life in the Ancient Near East. It was only natural that religion became a critical force in the way people sought the blessings that made life possible. Palestine has a Mediterranean climate, which means that at times rains "is exceedingly erratic" ${ }^{61}$ Under conditions like

God's People in God's Land (Grand Rapids, MI: Eerdmans, 1990), 5.

Ibid., 4.

In this sense see W. Zimmerly, Ezekiel 2 (Philadelphia, PA: Fortress Press, 1983), 246, for the concept of "land pollution" through disobedience (cf. Leviticus 18:28; Deuteronomy 21:23).

Thus J. G. Ploger, "adhamah", Theological Dictionary of the Old Testament, ed. by G. J. Botterweck (Grand Rapids, MI: Eerdmans, 1974, 1997), 1:88-98.

D. Baly, "Rain", The International Standard Bible Encyclopedia, ed. by G. Bromiley (Grand Rapids, MI: Eerdmans, 1992), 4:35-36. 
these, the dependence of people upon religions that promise to unleash the blessing of rain is a logical consequence. In this sense, the Israelites were faced with several competing options. Scripture affirms that rain is both a natural phenomenon and a blessing from God, the creator of all natural phenomena.

In contrast, Canaanite religion affirmed that rain was the manifestation of the graces of Baal, the storm god, whom worshippers had to appease in order to secure the blessing. One would assume that the Israelites approached this dilemma with an either/ or attitude. Few did, as the example of Elijah and others attest.

And Elijah came near to all the people and said, "How long will you go limping between two different opinions? If the LORD is God, follow him; but if Baal, then follow him". And the people did not answer him a word (1 Kings 18:21). ${ }^{62}$

In the mind of Elijah, God, not Baal, was the Creator and bestower of the blessing of rain. One would either serve God or Baal, but not both. Most people, however, adopted a more practical solution: syncretism. In essence, the Ancient Near Eastern world, as it was the case with Roman religion as well, believed that divinity manifested itself in a plurality of gods. Religion was the means through which the worshipper attracted the mysterious divine world to his or her side and somehow made it work in his or her favor. For most pagan worshippers, the relationship between humanity and the gods was characterized not so much by love and devotion, as by a contractual covenant in which both sides were expected to fulfill their responsibilities.

In a sense, as the Israelites conquered Canaan, they still bore a "minority" or "late comer" mentality, which predisposed them to assimilating the religious and cultural features of Canaanite inhabitants. Scholars have observed that the group of Moses came from a non-agricultural context-the wilderness. Since life in Canaan was essentially agricultural, this was exactly the point where YHWH and Baal would come into conflict. Thus the wilderness culture clashed with the more established agricultural culture of Canaan. ${ }^{63}$ As Mulder noted,

Since the Baal cult was synchronized with the cyclical events of nature, which had great significance for the agricultural population of Canaan, its fertility rites appeared obscene to the worshippers of Yahweh and their myths deifications of nature.

As one reads the Old Testaments from this perspective, two emerging worldviews come to the fore. On the one hand, the prophetic voices of the Old Testament refused to live this synergism. Namely, that YHWH and Baal are equal or that the Israelites are right to worship both of them. The prophetic ministry of Elijah in

62 Unless otherwise noted, translations of biblical texts come from the English Standard Version.

63 Thus M. J. Mulder, "Ba'al", Theological Dictionary of the Old Testament (Grand Rapids, MI: Eerdmans, 1975), 2:200.

PERICHORESIS $11.1(2013)$ 
itself represents the uncompromising view that Baal has no legitimacy and that worshipping him does in fact break the covenant of Moses. ${ }^{64}$ On the other hand, the majority of the people, at most of the critical periods in the history of Israel, did not find a problem with integrating Baal and YHWH worship. We already pointed out that "when Elijah accused the Israelites of 'limping on two crutches' (1 Kings 18:21), they said nothing" ${ }^{65}$ In this sense Elijah "attempted to replace the royal programme 'Yahweh and Baal' with the slogan 'Yahweh or Baal". ${ }^{66}$ Note then the reasoning of Hoseah on why Baal worship was so attractive:

And she did not know that it was I who gave her the grain, the wine, and the oil, and who lavished on her silver and gold, which they used for Baal. ${ }^{9}$ Therefore I will take back my grain in its time, and my wine in its season, and I will take away my wool and my flax, which were to cover her nakedness... ${ }^{21}$ And in that day I will answer, declares the LORD, I will answer the heavens, and they shall answer the earth, ${ }^{22}$ and the earth shall answer the grain, the wine, and the oil, and they shall answer Jezreel (Hosea 2:8-9, 21-22).

One will also notice that the prophetic answer set the Yahwistic vision of the source of rain and abundance against the Canaanite view that life and fertility were dependent on Baal. Evidently, this confrontation reveals that fact that the "majority" view was in fact the synergistic view. In other words, most people, at most times and in most communities of ancient Palestine adopted the view of "practical" polytheism. That is, even though they may have revered YHWH as their national God, in the day to day affairs, they appealed for help to Baal as well. ${ }^{67}$ In other words, with very small exceptions, the religious status quo embraced the benefits of religious pluralism. ${ }^{68}$ Again Mulder shows,

The important differences between the worshippers of Yahweh who immigrated from the wilderness and the settled agricultural worshippers of Baal could not prevent Israel from borrowing from the very first both secular and religious customs and practices, which were assimilated rather quickly from the settled population in Canaan... Ba'al's

Thus Albertz, The History of Israelite Religion, vol. 1 (London: SCM Press, 1994), 153. We pointed to Albertz's argument that "the Baal cult rose to preeminence during the reigns of Omri and Ahab, but that the tendency for syncretism had been there all along", and that "by the time of Elijah, many of the typical northern Israelites would have felt no remorse to call on Baal". Botica, "The Theophoric element Baal in Ancient Phoenician Inscriptions", 67-94. Rainertz, A History of Israelite Religion, 154.

67 Thus Stuart, Exodus (Nashville, TN: Broadman \& Holman, 2006), 452, for the possibility that the ancient Canaanites held to a three-layered view of divinity: the personal, the family and the national god. That is why for the family of Gideon, having an altar for Baal while venerating "the Lord" (YHWH) did not pose a conflict.

68 As M. Brennan Dick notes, Born in Heaven, Made on Earth: the Making of the Cult Image in the Ancient Near East (Winona Lake, IN: Eisenbrauns, 1999), 11, one of the earliest evidences of this problem comes from the ministry of Elijah, who insisted on the fundamental decision between Yahweh and Baal.

PERICHORESIS $11.1(2013)$ 
ability to be assimilated or to appear under different names could lead to the idea of a Baal polytheism.

Evidently, Canaanite practices had a profound materialistic and ideological impact upon ancient Israel as well (Deuteronomy 23:18-19, Amos 2:7-8, and Hosea 4:13). ${ }^{69}$ We already noted that since many viewed Baal as "the bringer of rain 'on which the fertility of the soil depends', in their mind, "Yahweh and Ba 'al differed but little". ${ }^{70}$

One instance in which the Old Testament indicates this is case of Ghedeon and the altars that his family had built for Baal and Asherah. We already indicated that pairing Baal with a feminine deity was an established practice in Canaan. ${ }^{71}$ Still, for many Israelites using cultic objects belonging to Asherah did not necessarily imply a rejection of Yahwistic devotion. Ghedeon appears to have been taught by his parents about the deeds of the Lord (Adonai) from Exodus (Judges 6:13). At the same time, based on the significance of the name of Ghedeon's father and the presence of the Asherah cult at his house, the family felt no discerning tension in mixing elements of the cult of Adonai, Ba'al and Asherah in their devotion. Many in Israel "regarded the Asherah cult objects as a legitimate part of Yahweh piety". ${ }^{72}$ Note, for example, the allusions to the worship of the Queen of Heavens (Ba alath) - the mistress, the lady-in Jeremiah 7:18 and 44:17, 25. Scholars have suggested that the whole family took part in venerating her. ${ }^{73}$

We believe it is safe to argue that "wherever Canaanites and Israelites lived side by side, there was the possibility of a far-reaching approximation of their religions" ${ }^{74}$ For many Israelites the name Baal (lord, master) was translated into the everyday interaction with nature. The Israelites behaved "as if the great life-giver is

69 See Botica, "The Theophoric element Baal in Ancient Phoenician Inscriptions", 67-94.

70 In this sense we pointed to Bright, "Hebrew Religion", Interpreters Dictionary of the Bible (Nashville, TN: Abingdon Press, 1962), 2:565; McKenzie, "God and Nature in the Old Testament", The Catholic Biblical Quarterly 14 (1952): 129ff; Scharlemann, "God is One", The Lutheran Quarterly 11.3 (1959): 235; Arnold, "Religion in Ancient Israel", The Face of Old Testament Studies, ed. by D. W. Baker (Grand Rapids, MI: Baker, 2004), 407; Mulder, "Ba'al”, TDOT, 2:196.

71 Thus J. Day, Yahweh and the Gods and Goddesses of Canaan (London: Continuum International Publishing, 2002), 131.

72 Miller, The Religion of Ancient Israel, 52ff. In addition, Miller argues that the anti-Ba' al purge of Jehu proves a fairly widespread phenomenon of syncretism both in north and south (e.g., 2 Kings 10:19ff). He classifies the attitudes of the ancient Israelites as "heterodox", "syncretistic" and "orthodox" Yahwism. Miller himself admits that it is not always clear whether one can distinguish among these three in all cases, places and at all times.

73 Holladay, Jeremiah 1, 254ff; Kaufmann, The Religion of Israel, 16; Keel, Gods, Goddesses, and Images of God, 294ff, 338; "The aim of this cult was the transmission of blessing in the form of sufficient food, health, and security (Jeremiah 44:17f.)". Similarly Stuckey, "Ancient Mother Goddesses and Fertility Cults", Journal of the Association for Research in Mothering 7.1 (2005), 38ff, for the possible association of the Queen of Heaven with Asherah, and hence with the idea of fertility and prosperity. Note also Miller, The Religion of Ancient Israel, 39-40.

74 In this sense note J. Goldingway, Old Testament Theology: Israel's Gospel, vol. 1 (Downers Grove, IL: Intervarsity Press, 2003), 534-35.

PERICHORESIS 11.1 (2013) 
not Yhwh but the Master". He is "the key to human fertility as he is the key to the fertility of crops and soil". The power of syncretism is evident in this very phenomenon. Yes, for many perhaps he is merely the God who delivered Israel from Egypt, but when the issue is one of ongoing life, that act might not seem so significant". Goldingway notes the irony in the act of serving Baal, in that the exodus from Egypt was designed to remove Israel from the service of Pharaoh to the service of Yhwh". Now, that the period of slavery belonged to the memory of their ancestors, the people adapted to worshiping Baal as "lord".

At the same time, the earliest sources in the history of the nation attest to the fact that not all Israelites accommodate to religious syncretism. For example, he noted that, since both versions of the Decalogue - as well as the majority of texts that address this problem- "contain the prohibition of images" it is very likely that this enactment goes back to the earliest days of Israelite religion. Furthermore, the very basis of the covenant lies not in religious mythology, but in affirmations of historical fact. This ancient expressions of faith pointed to the fact that faith "was connected with history" not with the reenactment of myth. ${ }^{75}$ In this sense,

The Israelites worshipped a personal God who intervened in history: Yahweh was the God of the Covenant. Their cult was not the re-enacting of myths about the origin of the world, as in Mesopotamia, nor of nature-myths, as in Canaan... Israel was the first nation to reject extra-temporal myths and to replace them by a history of salvation.

In Jeremiah 7:9, the prophet condemned the people for "swearing on Baal". The practice was sinful for two reasons. First, it broke the covenant that God established with his people Israel, by worshipping false gods. One will remember that the Decalogue begins with the assertion that God was the one who had brought Israel out of the "house of bondage". It was scandalous and false as well, for the Israelites to worship gods who had contributed nothing to their salvation from Egypt. Second, "swearing" by Baal was sinful because it implied the notion of "covenant partnership". That is, the people would swear invoking the name of the god with whom they entered into a covenantal relationship. Yet again, Baal had no such relationship with Israel. Swearing by his name would suggest, essentially, that Baal, not YHWH, was responsible for the covenant with Israel. ${ }^{76}$ The people would swear by Baal in order to secure the blessings of rain and fertility. In Jeremiah's view, they achieved only forfeiting the covenantal blessings and bringing upon them the covenantal curses.

In the same context, a number of scholars have shown that, "since the biblical writers did not intend to teach the Canaanite religion, we know more about Baal's

R. de Vaux, Ancient Israel (Grand Rapids, MI: Eerdmans, 1961, 1997), 272.

Thus W. Holladay, Jeremiah 1, Hermeneia (Philadelphia, PA: Fortress Press, 1986), 245.

PERICHORESIS $11.1(2013)$ 
roles, consorts, and cult from the extra-biblical literature than from the Old Testament". ${ }^{77}$ This, however, remains a relative judgment. True, Ancient Near Easter sources attest that, in the mentality of the Canaanite men, the dry seasons or entire years "were attributed to his temporary captivity or even death". In this sense, the coming to life of Baal brought new life to the ground that had been parched during the dry or the cold season. In this sense, the miracles that Elijah and Elisha performed may have "served as a polemic for God against the very powers attributed to this pagan nature deity, namely, fire (1 Kings 18:17ff; 2 Kings 1:9-16), rain (1 Kings 17:1; 1 Kings 18:41-46), food (1 Kings 17:1-6, 8-16; 2 Kings 4:1ff); children (2 Kings 4:14-17); revivification (1 Kings 17:17-23; 2 Kings 4:18-37; 2 Kings 13:2022". ${ }^{78}$

The Hosea discourse describes how Israel, who received gifts of grain and oil from YHWH, used these for the worship of Baal (Hosea 2:8 [H 10]). The chapter fairly turns on the term Baal, not only in the mention of the Canaanite god(s) (e.g. Hosea 2:8 [H 10]; Hosea 2:13 [H 15]; and Hosea 2:17 [H 19]), but in the imagery throughout of God as Israel's husband. Israel will call the Lord her husband ("ish", Hosea 2:16 [H 18]; cf. Hosea 2:2 [H 4]; Hosea 2:7 [H 9]) and no longer call him, apparently along with the list of other gods, my Baal.

Worshiping the sun was another dimension of the mentality that natural phenomena were a manifestation of the divine world. Sun worship was preeminent both in Egyptian and in Canaanite religious practices. Along with "rain", the sun was crucial for its role in agriculture. Solar worship is well documented in these religions, and it seems to have made inroads into Israelite practices. ${ }^{79}$ As 2 Kings 23:5 shows, king Manasseh facilitated the practice of worshipping the sun, even though the practice must have been brought much earlier in Israel (see Job 31:2628). The presence of sun worship can be attested by the names one finds associated with temples or important places (e.g., Beth-Shemesh [Joshua 15:10]). ${ }^{80}$

\section{The Language of Idolatry}

In a passage that plays on the irony of idol worship, the prophet Isaiah "contrasts the gods whose statues must be carried, with God who carries his people (Isa 46:1ff)" ${ }^{81}$ The terminology that Isaiah used in his prophecies is only a minor part of a larger spectrum of expressions describing this problem. The mere listing of the

"Baal", Theological Wordbook of the Old Testament, vol. 1, ed. by R. Laird Harris (Electronic Version, BibleWorks8, 1981). In fact, as Curtis shows, "Canaanite Gods and Religion", 140, the belief that YHWH may have had a consort seems to have taken root in ancient Israel too, which proves the assertion that among the populace religious syncretism could have been the norm rather than the exception.

$78 \quad$ Ibid.

79 D. T. Tsumura, “Canaan”, 129.

80 A. W. Curtis, "Canaanite Gods and Religion", 141.

81 "Baal”, Theological Wordbook of the Old Testament, vol. 1 (2013 BibleWorks 8, SoftwareVersion). 
many terms that the Old Testament uses to describe the experience of idolatry attests to how deeply rooted this experience was in the religious conscience of the biblical man.

\begin{tabular}{|c|c|c|c|}
\hline & Hebrew & Meaning & Old Testament Reference \\
\hline 1. & selem & $\begin{array}{l}\text { statue, effigy, } \\
\text { sculpture, image, } \\
\text { likeness }\end{array}$ & $\begin{array}{l}\text { (Ezechiel } 7: 20 \text { ) "His beautiful orna- } \\
\text { ment they used for pride, and they } \\
\text { made their abominable images and their } \\
\text { detestable things of it". }\end{array}$ \\
\hline 2. & pesel & $\begin{array}{l}\text { sculpted image, } \\
\text { sculpture }\end{array}$ & $\begin{array}{l}\text { (Exodus 20:4) "You shall not make for } \\
\text { yourself a carved image, or any likeness } \\
\text { of anything that is in heaven above, or } \\
\text { that is in the earth beneath, or that is in } \\
\text { the water under the earth". }\end{array}$ \\
\hline 3. & pasi/l & $\begin{array}{l}\text { representation, } \\
\text { image of a deity }\end{array}$ & $\begin{array}{l}\text { (Jeremiah } 8: 19 \text { ) "Why have they pro- } \\
\text { voked me to anger with their carved im- } \\
\text { ages and with their foreign idols?" }\end{array}$ \\
\hline 4. & temûnâ & $\begin{array}{l}\text { likeness, resem- } \\
\text { blance, image }\end{array}$ & $\begin{array}{l}\text { (Deuteronomy } 4: 25 \text { ) "When you father } \\
\text { children and children's children, and } \\
\text { have grown old in the land, if you act } \\
\text { corruptly by making a carved image in } \\
\text { the form of anything..." }\end{array}$ \\
\hline 5. & massekâ & $\begin{array}{l}\text { statue, image or } \\
\text { form cast from } \\
\text { melted metal or } \\
\text { gold }\end{array}$ & $\begin{array}{l}\text { (Isaiah 30:22) "Then you will defile } \\
\text { your carved idols overlaid with silver } \\
\text { and your gold-plated metal images". }\end{array}$ \\
\hline 6. & $s b$ & idol, image, form & $\begin{array}{l}\text { (Micah 1:7) "All her carved images shall } \\
\text { be beaten to pieces, all her wages shall } \\
\text { be burned with fire, and all her idols I } \\
\text { will lay waste". }\end{array}$ \\
\hline 7. & hebel & vanity, vain idol & $\begin{array}{l}\text { (Jeremiah 2:5) "Thus says the LORD: } \\
\text { "What wrong did your fathers find in } \\
\text { me that they went far from me, and } \\
\text { went after worthlessness, and became } \\
\text { worthless?" }\end{array}$ \\
\hline 8. & qibbîs & $\begin{array}{l}\text { things gathered, } \\
\text { collection, idols }\end{array}$ & $\begin{array}{l}\text { (Isaiah 57:13) "When you cry out, let } \\
\text { your collection of idols deliver you!" }\end{array}$ \\
\hline 9. & 'elohi/ m & $\begin{array}{l}\text { gods, heavenly } \\
\text { beings }\end{array}$ & $\begin{array}{l}\text { (Exodus } 12: 12 \text { ) “... and I will strike all } \\
\text { the firstborn in the land of Egypt, both }\end{array}$ \\
\hline
\end{tabular}




\begin{tabular}{|c|c|c|c|}
\hline & & & $\begin{array}{l}\text { man and beast; and on all the gods of } \\
\text { Egypt I will execute judgments". }\end{array}$ \\
\hline 10. & semel & $\begin{array}{l}\text { idol, likeness, im- } \\
\text { age }\end{array}$ & $\begin{array}{l}\text { (2 Chronicles } 33: 7 \text { ) "And the carved im- } \\
\text { age of the } i d o l \text { that he had made he set } \\
\text { in the house of God..." }\end{array}$ \\
\hline 11. & terapi/ $m$ & $\begin{array}{l}\text { statue, figurine, } \\
\text { household god, } \\
\text { ceremonial mask } \\
(?)\end{array}$ & $\begin{array}{l}\text { (Genesis 31:19) "Laban had gone to } \\
\text { shear his sheep, and Rachel stole her fa- } \\
\text { ther's household gods". }\end{array}$ \\
\hline 12. & tabni/ $t$ & $\begin{array}{l}\text { human likeness, } \\
\text { image, idol }\end{array}$ & $\begin{array}{l}\text { (Deuteronomy } 4: 16 \text { ) "Beware lest you } \\
\text { act corruptly by making a carved image } \\
\text { for yourselves, in the form of any fig- } \\
\text { ure, the likeness of male or female". }\end{array}$ \\
\hline 13. & gillûl & $\begin{array}{l}\text { idol, excrement, } \\
\text { trash }\end{array}$ & $\begin{array}{l}\text { (Ezechiel 8:10) "So I went in and saw. } \\
\text { And there, engraved on the wall all } \\
\text { around, was every form of creeping } \\
\text { things and loathsome beasts, and all the } \\
\text { idols of the house of Israel". }\end{array}$ \\
\hline 14. & 'elîl & $\begin{array}{l}\text { idol, worthless, } \\
\text { nothingness }\end{array}$ & $\begin{array}{l}\text { (Leviticus 26:1) "You shall not make } \\
\text { idols for yourselves or erect an image or } \\
\text { pillar, and you shall not set up a figured } \\
\text { stone in your land to bow down to it..." }\end{array}$ \\
\hline 15. & mașsëbâ & $\begin{array}{l}\text { commemorative } \\
\text { stone, pillar }\end{array}$ & $\begin{array}{l}\text { (Leviticus 26:1) "You shall not make } \\
\text { idols for yourselves or erect an image or } \\
\text { pillar, and you shall not set up a figured } \\
\text { stone in your land to bow down to it..." }\end{array}$ \\
\hline 16. & 'eben maśkît & $\begin{array}{l}\text { sculpture, object } \\
\text { with memorial } \\
\text { picture }\end{array}$ & $\begin{array}{l}\text { (Leviticus 26:1) "You shall not make } \\
\text { idols for yourselves or erect an image or } \\
\text { pillar, and you shall not set up a figured } \\
\text { stone in your land to bow down to it..." }\end{array}$ \\
\hline 17. & šiqqûs & $\begin{array}{l}\text { detestable, loath- } \\
\text { some, abhorrent } \\
\text { idol }\end{array}$ & $\begin{array}{l}\text { (Deuteronomy 29:17) "And you have } \\
\text { seen their detestable things, their idols of } \\
\text { wood and stone, of silver and gold, } \\
\text { which were among them". }\end{array}$ \\
\hline
\end{tabular}

\section{Later influences of Semitic Polytheism}

The deep link between weather, agriculture and religion seems to have been made by later Mediterranean nations as well. The parallels between Ugaritic, Canaanite and Greek myths are astounding and attest to heavy borrowing on the part of the 
Greeks. ${ }^{82}$ One will note that Ouranus/ Uranus, the god of the sky, and the most ancient of divinities, created the gods through sexual acts with Gaia, the goddess symbolizing the earth. ${ }^{83}$ This mentality appears at work both in ancient Sumerian (and later Babylonian) and Egyptian creation accounts. As Kaufman noted, the sexual activity of the gods is one of the fundamental presuppositions of all ancient religions. ${ }^{84}$ It informs all subsequent religious existence and practice and it obliges human worshippers to regard sexuality as an important force that brings the blessings of human, animal and natural life. Most of all the other deities engaged in sexual acts out of which originated both human and semi-divine beings and heroes.

A simple listing of Greek deities reveals the extent to which the ancient men and women credited the deities with control over the daily aspects of economic life. Burkert pointed out that, even though the axiom that the gods of mythology had originally been natural phenomena has been challenged, the relationship between the divine world and natural phenomenon can hardly be denied. The fact that each city worshipped its river or spring, that people held grandiose festivals in honor of the earth (goddess Gaia/ Ge), that a strong cult of the winds existed in Greece, and the high importance of the god Helios (Sun), attests to the importance of all natural phenomena for the pagan worshipper. ${ }^{85}$

Zeus (Jupiter in the Roman pantheon) violently gained control over the world of gods and married Hera (Juno), the patron of marital life and protector of women. Zeus ruled the sky and had power over storms and rains, in a manner reminiscent of the Canaanite god Baal. Zeus was a weather god ${ }^{86}$ Burkert recalls how Athenian children during the Imperial times were singing "Rain, rain, O dear Zeus, on the fields of the Athenians". ${ }^{87}$ A detail that that is often overlooked is the connection between fertility and worship of Zeus. Although scholars have rarely associated Zeus with "fertility" worship, one must not dismiss the relevance of the high number of children that Zeus fathered and-according to the number counted by mythographers-the one hundred and fifteen mistresses who had sexual relationships with Zeus. ${ }^{88}$ The fact that, in addition to being the "god of rain", Zeus was the father of gods and men, remains a critical detail in establishing the link between religion and sexuality/ fertility for the ancient worshippers. One needs only take into account the

R. Rosenzweig, Worshiping Aphrodite: art and cult in classical Athens (Ann Arbor, MI: University of Michigan Press, 2004), 122.

J. Kindt, Rethinking Greek Religion (Cambridge: Cambridge University Press, 2002), 23. The Religion of Israel, 16.

W. Burkert, Greek Religion (Harvard, MA: Harvard University Press, 1987), 174-76.

Thus J. N. Brenner, "The Greek God in the Twentieth Century”, Gods of Ancient Greece: Identities and Transformations, ed. by J. N. Bremmer, A. Erskine (Edinburgh: Edinburgh University Press, 2010), 13ff, A. B. Cook, Zeus: A Study in Ancient Religion, vol. 2, part 1 (Cambridge: Cambridge University Press, 1914), $1 \mathrm{ff}$.

Ibid., 126.

Ibid., 128. 
scene of the sexual encounter between Zeus and Hera, to grasp the significance of this link. ${ }^{89}$

Just like in Canaanite mythology, the Greeks feared the ominous world of waters and venerated the god Poseidon (Neptune), the patron of seas and oceans. The sea was a critical source of life for all Mediterranean cultures. That is why Poseidon occupied an important place in the religious conscience of the Greeks and Romans. He was perceived as a dangerous god who threatened humanity with floods and other calamities. ${ }^{90}$ Just like the Oriental cultures, the Greeks had a well-established calendar of sacrifices and celebrations in honor of the patron gods. ${ }^{91}$ For example, Apollo and his twin sister Artemis (Diana) were believed to exercise control over natural life; in particular, over wild animals. Artemis had a strong following among women and, in particular, women who were expecting a child. She was celebrated at the festival of Brauronia. ${ }^{92}$ In Greek art Apollo appears often times in the form of the sun, another forceful symbols. Apollo was celebrated in the Hekathombaion, a feast held in the middle of the Summer season. ${ }^{93}$ Along with Aphrodite, Artemis symbolized the power of female sexuality. ${ }^{94}$ Aphrodite was worshipped in the South-Western hemisphere. In Corinth, the Temple of the goddess was an attractive avenue, possibly because of its association with sacred prostitution. ${ }^{95}$ In fact, for the Greeks the name Aphrodisia recalled both the festival held in honor of the goddess and the feeling of "sexual desires". ${ }^{96}$

The goddess Demeter was the patron of agricultural life, as she symbolized the force that assured the blessings of crops. The fact that she was venerated in the arms, the earth sprouts forth grass and flowers, and a golden cloud descends over everything, so they embrace on the peak of Mount Ida in the sacred precinct".

90 Thus R. Parker, "Myths of Early Athens", Interpretations of Greek Mythology, ed. by J. Bremmer (Florence, KY: Taylor \& Francis, 1987), 199ff.

91 Thus J. R. Brandt et. all, Greek and Roman Festivals: Content, Meaning and Practice (Oxford: Oxford University Press, 2012); B. D. Meritt, The Athenian Year (Fresno, CA: University of California Press, 1961), 209ff.

92 See M. Dillon, Pilgrims and Pilgrimage in Ancient Greece (Florence, KY: Routledge, 1997), 201ff, and also Mikalson, Ancient Greek Religion, 49-50.

93 See J. Neils, "The Political Process in the Public Festival. The Panathenaic Festival of Athens", Greek and Roman Festivals: Content, Meaning and Practice, 199-216, for the fact that the goddess Athena was venerated as a patron and was celebrated during the Summer, in the festival of Panathenaia.

94 Thus Burkert, Greek Religion, 151, for the special role that Artemis played in the life of young girls, especially as they came of age in approaching courtship and marriage.

95 Mikalson, Ancient Greek Religion, 139; R. Rosenzweig, Worshiping Aphrodite: art and cult in classical Athens, 122; V. P. Furnish, II Corinthians (New York: Doubleday, 1984), 16.

96 Thus Liddell and Scott, Greek English Lexicon (Oxford: Oxford University Press, 1968), 293. Burkert, Greek Religion, 152-53, points out that the verb aphrodisiazein, which "denotes quite simply the act of love". One may also observe the relation between the "the old abstract noun for sexual desires, eros" and Eros, the son of Aphrodite, who became the god of stirring the feelings of love.

PERICHORESIS 11.1 (2013) 
Eleusian Mysteries attests to the powerful following she commanded in the pagan thought. ${ }^{97}$ The Eleusian Mysteries were celebrated during the Fall, the most important of all agricultural seasons of the ancient world. In particular, women celebrated the Thesmophoria, an event that centered around all matters regarding feminity. ${ }^{98}$ Scholars have also noted an association between Demeter and the god Dionysus or Bacchus: the overseer of vineyards and the god of wine and debauchery, who was celebrated in the Feast of Dyonisia. ${ }^{99}$

In sum, one may argue that, because of the character of Greek deities, the worshipers shared a feeling of reverence, duty or even admiration towards the gods, but never one of love. In fact, for a Greek to say Zeus is a love would have sounded unnatural and strange. ${ }^{100}$ If one views the phenomenon of Greek religion in light of its Ancient Near Eastern context, then he or she must observe the parallels between the moral character of the Semitic and the Greek gods.

\section{Conclusion}

As B. T. Arnold pointed out, the topic of religion in ancient Israel remains one of the most debated themes in Old Testament studies. ${ }^{101}$ There exists little or no consensus over the notion of "orthodox" or "minority" religion, other than the fact the Canaanite practices were indeed present among the populace of Israel. A number of scholars have argued that monotheism emerged as a serious challenge to syncretism only during the second part of the monarchy, mainly through the reforms of kings Hezekiah and Josiah (e.g. Mark Smith). Others have contended that both epigraphic and Old Testament data paint a different picture. That is, Yahwism must have made a powerful impact long before the reigns of David and Solomon (Tigay, de Moore). Cross and T. N. D. Mettinger too argued that the essentials of Yahwism can be traced to early evidence from Egypt, thus possibly linking the faith of Moses with the Exodus from Egypt. If scholars are right, namely, that the practice of idolatry is attested and existed from the earliest manifestations of human religious activities, then there should be little reason to doubt that the Biblical picture is accurate in its chronological perspective. We want to argue that the Biblical authors never thought of presenting Israel in a positive light. On the contrary, the numerous condemnations against idolatry in the Bible confirm the fact that Israel had a that the most important and popular of the Greek mysteries "were those of Demeter and Kore at Eleusis".

One may also note Meyer, The Ancient Mysteries, 113ff, for the importance of the myth of Magna Mater (the Great Mother) for the inhabitants of Phrygia (central Anatolia), a myth that had echoes even in later Roman times.

K. Buraselis, "The Coordination and Combination of Traditional Civic and Ruler Cult Festivals in the Hellenistic and Roman East", Greek and Roman Festivals: Content, Meaning and Practice, 24766.

100 Thus J. D. Mikalson, Ancient Greek Religion (London: John Wiley \& Sons, 2010), 21.

101 B. Arnold, "Religion in Ancient Israel", The Face of Old Testament Studies: A Survey of Contemporary Approaches, ed. by D. W. Baker and B. T. Arnold (Grand Rapids, MI: Baker, 1999), 391-420. 
worldview that drew a sharp distinction between God and the gods and that, even though the majority of the people embraced syncretism, this way of life had never been the ideal for the people of God.

\section{Bibliography}

Armerding, C. E. "Festivals and Feasts". Dictionary of the Old Testament Pentateuch. Eidted by T. D. Alexander. Downers Grove, IL: Intervarsity Press, 2003, 300313.

Arnold, B. T. "Religion in Ancient Israel". The Face of Old Testament Studies: A Survey of Contemporary Approaches. Edited by D. W. Baker and B. T. Arnold. Grand Rapids, MI: Baker, 1999, 391-420.

. Readings from the Ancient Near East: Primary Sources for Old Testament Study. Ada, MI: Baker Academic, 2002.

Baly, D. "Rain". The International Standard Bible Encyclopedia. Edited by G. Bromiley. Grand Rapids, MI: Eerdmans, 1992, 4:35-36.

Botica, A. "The Theophoric element Baal in Ancient Phoenician Inscriptions". Perichoresis 10.1 (2012): 67-94.

. "When Heaven is Shut up. Ancient Near Eastern Backgrounds to the Concept of Natural Calamity”. Perichoresis 4.1 (2006): 95-115.

Brandt, J. R. Greek and Roman Festivals: Content, Meaning and Practice. Oxford: Oxford University Press, 2012.

Brennan D. M. Born in Heaven, Made on Earth: the Making of the Cult Image in the Ancient Near East. Winona Lake, IN: Eisenbrauns, 1999.

Brenner, J. N. "The Greek God in the Twentieth Century". Gods of Ancient Greece: Identities and Transformations. Edited by J. N. Bremmer and A. Erskine. Edinburgh: Edinburgh University Press, 2010, 1-18.

Bright, J. A History of Israel. Third edition. Philadelphia, PA: Westminster, 1981.

Block, D. "God (1.5. Ba'al)". Dictionary of Old Testament Historical Books. Edited by B. T. Arnold. Downers Grove, IL: Intervarsity Press, 2005.

Burkert, W. Greek Religion. Harvard, MA: Harvard University Press, 1987.

Christensen, D. L. Deuteronomy 1:1-21:9. Second edition. Word Biblical Commentary. Nashville, TN: Thomas Nelson, 2001.

Cook, A. B. Zeus: A Study in Ancient Religion. Volume two, part 1. Cambridge: Cambridge University Press, 1914.

Craigie, P. "Religions: Canaan”. International Standard Bible Encyclopedia. Edited by W. Bromiley. Grand Rapids, MI: Eerdmans, 1988, 95-101.

Cross, F. M. Canaanite Myth and Hebrew Epic: Essays in the History of the Religion of Israel. Harvard, MA: Harvard University Press, 2009.

Curtis, A. H. W. "Canaanite Gods and Religion". Dictionary of the Old Testament Historical Books. Edited by B. T. Arnold. Downers Grove, IL: Intervarsity Press, 2005.

PERICHORESIS $11.1(2013)$ 
Day, J. Yahweh and the Gods and Goddesses of Canaan. London: Continuum International Publishing, 2002.

de Vaux, R. Ancient Israel. Grand Rapids, MI: Eerdmans, 1997.

Dillon, M. Pilgrims and Pilgrimage in Ancient Greece. Florence, KY: Routledge, 1997.

Eichrodt, W. Theology of the Old Testament. Volume one. Philadelphia, PA: Westminster Press, 1961.

Furnish, V. P. II Corinthians. New York: Doubleday, 1984.

Free, J. P. Archaeology and Bible History. Revised by H. F. Voss. Grand Rapids, MI: Zondervan, 1992.

Goldingway, J. Old Testament Theology: Israel's Gospel. Volume one. Downers Grove, IL: Intervarsity Press, 2003.

Goldingay J. Old Testament Theology: Israel's Faith. Volume two. Downers Grove, IL: Intervarsity Press, 2006.

Hallo, W. The Context of Scripture. Canonical Compositions from the Biblical World. Leiden: Brill, 1997.

Holladay, W. "Jeremiah 1". Hermeneia. Philadelphia, PA: Fortress Press, 1986.

Kapelrud, A. S. Baal in the Ras Shamra Texts. Copenhagen: G. E. C. Gad, 1952.

Kaufmann, Y. The Religion of Israel. Translated by M. Greenberg. New York: Schoken Books, 1960.

Kronholm, T. "Sakak". Theological Dictionary of the Old Testament. Edited by G. H. Botterweck. Grand Rapids, MI: Eerdmans, 1999, 10:236-54.

Kindt J. Rethinking Greek Religion. Cambridge: Cambridge University Press, 2002, 23.

Lang, B. "kipper". Theological Dictionary of the Old Testament. Edited by G. H. Botterweck. Grand Rapids, MI: Eerdmans, 1995, 7:289-303.

Meritt, B. C. The Athenian Year. Fresno, CA: University of California Press, 1961.

Meyer M. W. ed. The Ancient Mysteries. San Francisco, CA: Harper, 1987.

Mikalson, J. D. Ancient Greek Religion. London: John Wiley \& Sons, 2010.

Montgomery, J. A. "Ras Shamra Notes IV: The Conflict of Baal and the Waters". Journal of the American Oriental Society 55.3 (1935), 268-277.

Mulder, M. J. "Ba'al". Theological Dictionary of the Old Testament. Grand Rapids, MI: Eerdmans, 1975, 2:200.

Neils, J. "The Political Process in the Public Festival. The Panathenaic Festival of Athens". Greek and Roman Festivals: Content, Meaning and Practice. Oxford: Oxford University Press, 2012, 199-216.

Ostborn, G. Yahweh and Baal. Studies in the Book of Hoseah and Related Documents. Malm, Sweden: C. W. K. Gleerup, 1956.

Parker, R. "Myths of Early Athens". Interpretations of Greek Mythology. Edited by J. Bremmer. Florence, KY: Taylor \& Francis, 1987.

Ploger, J. G. "adhamah", Theological Dictionary of the Old Testament. Edited by G. J. Botterweck. Grand Rapids, MI: Eerdmans, 1974, 1997, 1:88-98. 
Pritchard, J. B. Ancient Near Eastern Texts. Third edition with supplement. Princeton, NJ: Princeton, 1974.

Rosenzweig, R. Worshiping Aphrodite: Art and Cult in Classical Athens. Ann Arbor, MI: University of Michigan Press, 2004.

Schaeffer, C. The Cuneiform Texts of Ras Shamra-Ugarit. London: Brittish Academy, 1939.

Smith, M. The Early History of God. Grand Rapids, MI: Eerdmans, 2002.

The Cuneiform Alphabetic Texts from Ugarit, Ras Ihn Hani, and Other Places. KTU second edition. Edited by M. Dietrich, O. Loretz, J. Sanmartin. Münster: UgaritVerlag, 1995.

Tsumura, D. T. "Canaan". Dictionary of the Old Testament Historical Books. Edited by B. T. Arnold. Downers Grove, IL: Intervarsity Press, 2005.

Uehlinger, K. Gods, Goddesses and Images of God in Ancient Israel. Minneapolis, MN: Fortress Press, 1998.

Van Dam, C. "Golden Calf". Dictionary of the Old Testament Pentateuch. Edited by T. D. Alexander. Downers Grove, IL: Intervarsity Press, 2003, 368-71.

Violita, A. C. "The Role of Migrants in the Transfer of Culture and Acculturation". Frontiers in Migration Analysis. Edited by R. B. Mandal. New Delhi, India: Concept Publishing Company, 1981.

Wyatt, N. Religious Texts from Ugarit. London: Continuum International Publishing, 2002.

Wright, D. P. "Day of Atonement". Anchor Bible Dictionary. Edited by D. N. Freeman. New York: Doubleday, 1992, 2:72-76.

Wright, C. J. H. Old Testament Ethics for the People of God. Downers Grove, IL: Intervarsity Press, 2004.

God's People in God's Land. Grand Rapids, MI: Eerdmans, 1990, 5.

Zobel, H.-J. "matar". Theological Dictionary of the Old Testament. Edited by G. J. Botterweck. Grand Rapids, MI: Eerdmans, 1997, 8:250-65. 